\title{
Biomass components of Pennisetum purpureum cv. Roxo managed at different growth ages and seasons
}

\section{Componentes da biomassa em "Pennisetum purpureum" cv. Roxo manejado sob diferentes idades e épocas de crescimento}

\author{
MARANHÃO, Theyson Duarte ${ }^{1 *}$; CÂNDIDO, Magno José Duarte ${ }^{1}$; LOPES, Marcos \\ Neves ${ }^{1}$; POMPEU, Roberto Cláudio Fernandes Franco ${ }^{2}$; CARNEIRO, Maria Socorro de \\ Souza $^{1}$; FURTADO, Rafael Nogueira ${ }^{1}$; SILVA, Rafael Rodrigues da ${ }^{1}$; ALVES, \\ Francisco Gleyson da Silveira ${ }^{1}$
}

\author{
${ }^{1}$ Universidade Federal do Ceará, Centro de Ciências Agrárias, Departamento de Zootecnia, Fortaleza, \\ Ceará, Brasil. \\ ${ }^{2}$ Embrapa Caprinos e Ovinos, Sobral, Ceará, Brasil. \\ *Endereço para correspondência: theysonduarte@gmail.com
}

SUMMARY

This study was carried out aiming to evaluate the biomass components of elephant grass cv. Roxo at seven growth ages, during rainy, transition and dry seasons. A completely randomized design was adopted with a split plot arrangement over time. The treatments consisted of seven growth ages ( 9 , $18,27,36,45,54$ and 63) and three seasons (rainy, transition and dry). The variables green forage biomass, dead forage biomass, green stem biomass and green leaf blade biomass showed positive linear responses to age and had their magnitude influenced by the evaluated seasons. The live/dead material ratio showed a decreasing linear response as a function of age. The leaf blade/stem ratio showed a negative linear adjustment in the rainy season, reaching a critical value of 1.0 at 59 days, and it showed a quadratic adjustment in the transition season, with the maximum point at 27.53 days; however, this ratio was not influenced by age in the dry season, revealing an average value of $2.22 \pm 0.27$. The canopy height and leaf area index showed a positive linear response toage in the three seasons. Tiller population density showed quadratic behaviour for age, with maximum estimated values of 134 and 110 til. $\mathrm{m}^{-2}$ at 31.24 and 37.40 days in the rainy and dry seasons, respectively. Rainfall seasonality influences the magnitude of the daily increase of the distinct biomass components of Pennisetum purpureum cv. Roxo.

Keywords: canopy structure, elephant grass, seasonality

\section{RESUMO}

Objetivou-se avaliar os componentes da biomassa em capim-elefante cv. Roxo em sete idades de crescimento, nas épocas chuvosa, transição e seca. Adotou-se um delineamento inteiramente casualizado, em arranjo de parcelas subdivididas no tempo. Os tratamentos consistiram em sete idades de crescimentos $(9 ; 18 ; 27 ; 36 ; 45 ; 54$ e 63 dias) e três épocas (chuvosa, transição e seca). As variáveis biomassa de forragem verde, forragem morta, colmo verde e de lâmina foliar verde apresentaram resposta linear positiva para o fator idade e tiveram suas magnitudes influenciadas pelas épocas de avaliação. A relação material vivo/material morto respondeu de forma linear decrescente em função das idades. A relação lâmina foliar/colmo apresentou ajuste linear negativo na época chuvosa, atingindo valor crítico de 1,0 aos 59 dias e ajuste quadrático na época de transição, com ponto de máxima aos 27,53 dias, e não foi influenciada pelo fator idade na época seca, com valor médio de $2,22 \pm 0,27$. A altura do dossel e o índice de área foliar responderam de forma linear positiva para $o$ fator idade, nas três épocas. A densidade populacional de perfilhos apresentou comportamento quadrático para o fator idade, com valores máximos estimados em 134 e 110 perf. $\mathrm{m}^{-2}$ aos 31,24 e 37,40 dias de idade nas épocas chuvosa e seca, respectivamente. A sazonalidade da precipitação pluvial influencia a magnitude do incremento diário nos distintos componentes da biomassa em Pennisetum purpureum cv. Roxo.

Palavras-chave: estacionalidade, estrutura do dossel, Capim-elefante 


\section{INTRODUCTION}

Elephant grass (Pennisetum purpureum) is widespread in tropical and subtropical regions, and it can be managed under grazing or cutting, due to its good agronomic characteristics, such as adaptation to different soil and climatic conditions, high productivity, perenniality, and responsiveness to management. The morphophysiological characteristics are conditioned by the abiotic factors to which the canopy is submitted, since, although the expression of morphogenic characteristics is genetically determined, its magnitude is influenced by extrinsic factors, and thus morphogenesis is the determining event for the canopy structure (CHAPMAN \& LEMAIRE, 1993). However, morphological modifications of the structural components of the canopy, implied in the qualitative characteristics of the biomass, are detrimental to the accumulation of carbon in plant organs of lower nutritional value during forage development.

In tropical regions, the variability of rainfall is the most inductive abiotic factor of phenotypic plasticity of forage plants managed under waterless conditions. Biomass production is another variable strongly influenced by climatic changes. Alencar et al. (2009), working with six grasses of different genera, verified effects of the seasonality on the variable total forage biomass.

The recommendations in the literature for the ideal cutting time of $P$. purpureum are based on variables such as height, chronological age or number of internodes (ANDRADE \& GOMIDE, 1971); however, such recommendations are used for canopies under optimal conditions for the development of the culture. It is also difficult to find models in the literature that allow an estimation of the ideal cutting time of this grass in different edaphoclimatic conditions with satisfactory levels of precision, including both productive and qualitative indexes. This study aimed to evaluate the biomass components of elephant grass cv. Roxo at seven growth ages, during rainy, transition and dry seasons.

\section{MATERIAL AND METHODS}

The study was carried out in a canopy of elephant grass (Pennisetum purpureum) cv. Roxo established in 2007, cultivated in sandstone yellow clay soil, belonging to the Núcleo de Ensino e Estudos em Forragicultura of the Departamento de Zootecnia of the Centro de Ciências Agrárias of Universidade Federal do Ceará - NEEF/DZ/CCA/UFC, located in Fortaleza, CE.

According to Köeppen's classification, the region has an Aw' rainy tropical climate type. Cumulative rainfalls of $373.30,17.30$ and $9.60 \mathrm{~mm}$ for the rainy, transition and dry seasons were recorded, respectively. The potential evapotranspiration of the crop was estimated as 39.43, 46.11 and $52.58 \mathrm{~mm}$ day $^{-1}$ for the rainy, transition and dry seasons, respectively (Figure 1).

The treatments consisted of seven growth ages $(9,18,27,36,45,54$ and 63 days) and three seasons (rainy, transition and dry) with three replicates (plots of $3.0 \times 3.5 \mathrm{~m}$ ). A completely randomised design with a split plot arrangement was adopted, where the growth ages were the plots, and the evaluation seasons were the subplots. 


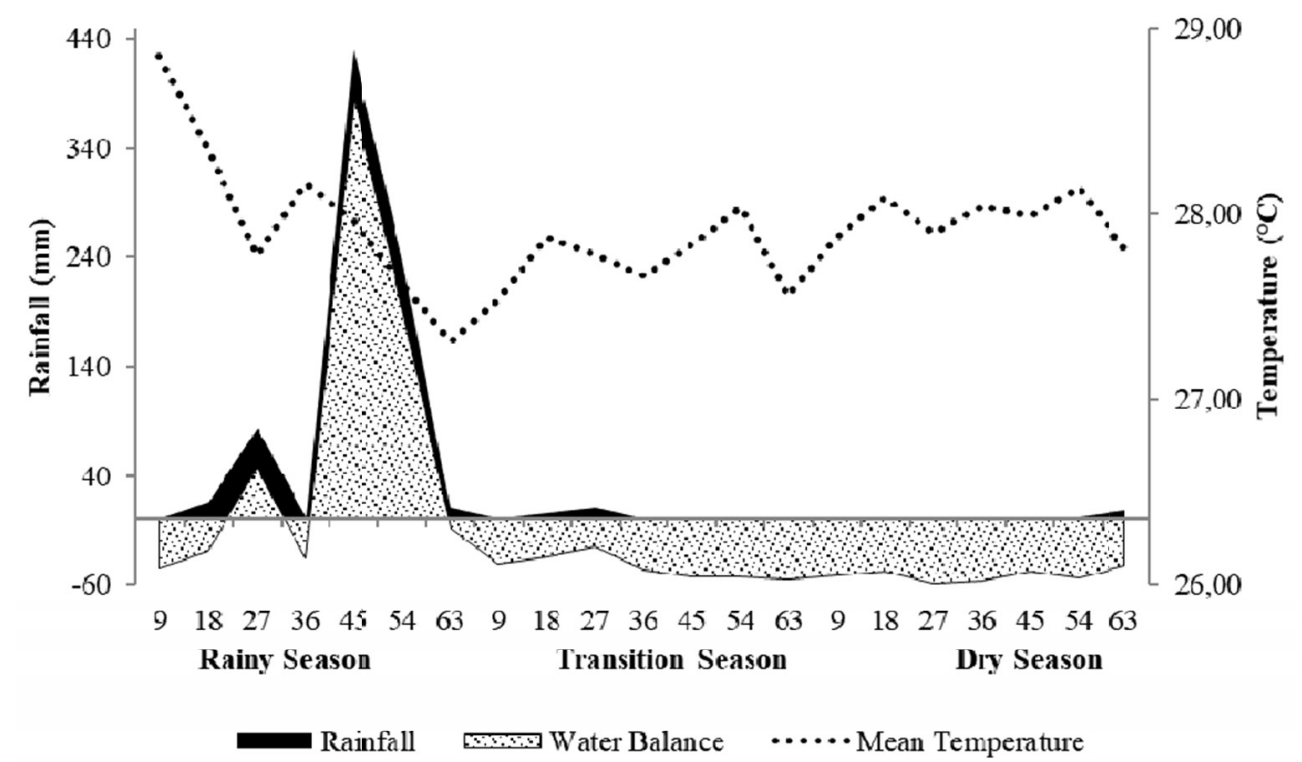

Figure 1. Climatic data of the experimental period

The soil analysis of the $0-20 \mathrm{~cm}$ depth layer performed at the beginning of each

season revealed the chemical characteristics presented in Table 1 . Maintenance fertilisation was carried out

only at the beginning of the rainy season, as recommended by the Soil Fertility Commission of the State of MinasGerais - CFSEMG (1999). Nitrogen fertilisation corresponded to the equivalent dose of $600 \mathrm{~kg} \mathrm{ha}^{-1}$ year $^{-1}$ of nitrogen, with urea

as the source $(45 \%$ of $\mathrm{N})$. Potassium fertilisation corresponded to the equivalent dose of $200 \mathrm{~kg} \mathrm{ha}^{-1}$ year $^{-1}$ of

$\mathrm{K}_{2} \mathrm{O}$, with potassium chloride as the source $\left(60 \% \mathrm{~K}_{2} \mathrm{O}\right)$. Micronutrient supply corresponded to the equivalent dose of $50 \mathrm{~kg} \mathrm{ha}^{-1}$ year $^{-1}$ of FTE BR-12.

Table 1. Chemical characteristics of the soil in each experimental season

\begin{tabular}{|c|c|c|c|c|c|c|c|c|c|c|c|}
\hline \multirow{2}{*}{ Season } & $\mathrm{P}$ & $\mathrm{K}$ & $\mathrm{Ca}^{2+}$ & $\mathrm{Mg}^{2+}$ & $\mathrm{Al}^{3+}$ & $\mathrm{Na}^{+}$ & $\mathrm{S}$ & $\mathrm{T}$ & OM & SB & $\mathrm{pH}$ \\
\hline & \multicolumn{2}{|c|}{$\mathrm{mg} \mathrm{dm}^{-3}$} & \multicolumn{6}{|c|}{$\mathrm{cmol}_{\mathrm{c}} \mathrm{dm}^{-3}$} & $\mathrm{~g} \mathrm{~kg}^{-1}$ & $\%$ & $\mathrm{H}_{2} \mathrm{O}$ \\
\hline Rainy & 179.0 & 58.6 & 3.8 & 2.3 & 0.40 & 0.06 & 6.3 & 8.8 & 14.6 & 72 & 5.4 \\
\hline Transition & 177.0 & 39.1 & 2.5 & 2.1 & 0.30 & 0.04 & 4.8 & 6.6 & 10.0 & 73 & 5.9 \\
\hline Dry & 165.0 & 58.7 & 2.8 & 2.3 & 0.40 & 0.05 & 5.3 & 7.1 & 13.7 & 75 & 5.9 \\
\hline
\end{tabular}

Phosphorus $(\mathrm{P})$, potassium $(\mathrm{K})$, calcium $(\mathrm{Ca})$, magnesium $(\mathrm{Mg})$, aluminum $(\mathrm{Al})$, sodium $(\mathrm{Na})$, sulphur $(\mathrm{S})$, total cation exchange capacity $(\mathrm{T})$, organic matter $(\mathrm{OM})$, sum of bases $(\mathrm{SB})$, hydrogen ionic potential $(\mathrm{pH})$.

The height was measured with a retractable graduated rod. For sampling of biomass in the experimental units and quantification of tiller population quantified, then all the biomass was cut close to the soil and taken to the laboratory, where it was weighed and separated into leaf blades, stems and 
Rev. Bras. Saúde Prod. Anim., Salvador, v.19, n.1, p.11-22 jan./mar., 2018

ISSN 15199940 http://dx.doi.org/10.1590/S1519-99402018000100002

density (TPD, tiller $\mathrm{m}^{-2}$ ), a frame of 1.0

dead material (senescent leaves and

$\mathrm{m}^{2}$ was used. In each plot, the number

stems). Subsequently, the fractions of

of live tillers inside the frame was

the harvested sample were weighed, 
packed into paper bags, and put in a forced ventilation oven at $55^{\circ} \mathrm{C}$ until they reached constant weight. Thus, pre-dried forage biomass was obtained and used to estimate the biomass of green forage (GFB, $\mathrm{kg} \mathrm{ha}^{-1}$ ), dead forage (DFB, $\mathrm{kg} \mathrm{ha}^{-}$ $\left.{ }^{1}\right)$, green stem (GSB, $\left.\mathrm{kg} \mathrm{ha}^{-1}\right)$, green leaf blade (GLB, $\mathrm{kg} \mathrm{ha}^{-1}$ ), leaf blade/stem ratio $(\mathrm{LB} / \mathrm{S})$ and live material/dead material ratio (LM/DM). For quantification of leaf area index, a 25leaf-blade aliquot was used. Those leaves had their ends cut so that the leaf blade had a rectangular shape of a predefined length $(10 \mathrm{~cm})$; then, they were weighed and had their widths measured, to obtain the mean value. From the product (length $\mathrm{x}$ mean width), the leaf area per unit of fresh biomass of the studied aliquot was obtained, allowing a proportionality criterion to be established with the sampled green leaf blade biomass, according to the method described by Benincasa (2003).

The data were submitted to analysis of variance, mean comparison test and regression analysis. The age $\mathrm{x}$ time interaction was deployed by the $\mathrm{F}$ test. The seasons (rainy, transition and dry) were compared using a Tukey test $(p<0.05)$. The effect of age was evaluated by regression analysis in the conditioned effect. Models were chosen based on the significance of the linear and quadratic coefficients, using Student's $t$ test and the coefficient of determination $\left(\mathrm{R}^{2}\right)$. As a tool to perform statistical analysis, the MIXED procedure of SAS 9.0 (SAS INSTITUTE, 2002) was adopted.

\section{RESULTS AND DISCUSSION}

An interaction between age and season $(p<0.05)$ was observed for all evaluated variables. Until 18 days of age there was no difference between seasons for the analysed variables (Table 2). It is likely that regrowth was more related to the mobilisation of reserves from the rhizomes (DAVIDSON \& MILTHORPE, 1966), indicating that the highest harvest frequencies did not compromise regrowth vigor, as the regrowth periods progressed

Daily increases in green forage biomass (GFB) of 201.3, 99.0 and $45.1 \mathrm{~kg} \mathrm{ha}^{-1}$ were estimated for the rainy, transition and dry seasons, respectively (Table 2), corroborating a distribution of 54.1, 29.9 and $15.8 \%$ of GFB (sum of three seasons) in the experimental period, which was a reflex of the rainfall distributions of 96.6, 2.2 and $1.2 \%$ (rainy, transition and dry, respectively) of the total rainfall in the experimental period.

Considering the irregular rainfall in semiarid regions of Brazil, it is notable that there is the necessity to increase the harvest frequency of forage managed in waterless conditions, allowing a greater number of cycles in the periods of greater water availability.

Subsequent seasons presented negative water balance for all evaluated ages. Water restriction causes an increase in the synthesis of abscisic acid, a hormone responsible for the stimulation of root growth, inhibition of stem growth and increased leaf abscission (SHARP, 2002). It is likely that elephant grass cv. Roxo prioritised its photoassimilates to the root meristems, increasing their agronomic efficiency, with the use of water present in the subsurface horizons. This hypothesis was reinforced by Dong et al. (2012), who observed an increase in the root biomass of rhizomatous grass, managed under water deficit. 
Table 2. Biomass components of elephant grass cv. Roxo managed at different ages and seasons of growth

\begin{tabular}{|c|c|c|c|c|c|c|c|c|c|}
\hline \multirow{2}{*}{ Season } & \multicolumn{7}{|c|}{ Growth Age (days) } & \multirow{2}{*}{ Equations } & \multirow{2}{*}{$\mathrm{R}^{2}$} \\
\hline & 9 & 18 & 27 & 36 & 45 & 54 & 63 & & \\
\hline Rainy & $89.3^{\mathrm{A}}$ & $876.3^{\mathrm{A}}$ & $1810.3^{\mathrm{A}}$ & $6192.0^{\mathrm{A}}$ & $6178.7^{\mathrm{A}}$ & $9678.8^{\mathrm{A}}$ & $9673.8^{\mathrm{A}}$ & $\mathrm{GFB}=-2318.295+201.298 * * *$ Age & 0.92 \\
\hline Transition & $148.1^{\mathrm{A}}$ & $514.5^{\mathrm{A}}$ & $893.8^{\mathrm{A}}$ & $1201.2^{\mathrm{B}}$ & $3059.0^{\mathrm{B}}$ & $4066.1^{\mathrm{B}}$ & $5375.4^{\mathrm{B}}$ & GFB $=-1384.614+99.009 * * *$ Age & 0.91 \\
\hline Dry & $170.9^{\mathrm{A}}$ & $491.7^{\mathrm{A}}$ & $925.8^{\mathrm{A}}$ & $1239.2^{\mathrm{B}}$ & $1724.7^{\mathrm{C}}$ & $1790.6^{\mathrm{C}}$ & $2829.4^{\mathrm{C}}$ & GFB $=-314.27+45.128 * * *$ Age & 0.96 \\
\hline Mean & 136.0 & 627.5 & 1218.9 & 2877.5 & 3654.1 & 5178.5 & 5870.9 & & \\
\hline Rainy & - & $1.4^{\mathrm{A}}$ & $10.3^{\mathrm{A}}$ & $416.3^{\mathrm{A}}$ & $692.6^{\mathrm{A}}$ & $1306.1^{\mathrm{A}}$ & $1979.1^{\mathrm{A}}$ & $\mathrm{DFB}=-1072.410+44.610 * * *$ Age & 0.91 \\
\hline Transition & - & $1.7^{\mathrm{A}}$ & $4.6^{\mathrm{A}}$ & $32.3^{\mathrm{B}}$ & $209.8^{\mathrm{B}}$ & $582.7^{\mathrm{B}}$ & $930.0^{\mathrm{B}}$ & $\mathrm{DFB}=-549.088+20.804 * * *$ Age & 0.83 \\
\hline Dry & - & $3.5^{\mathrm{A}}$ & $17.9^{\mathrm{A}}$ & $26.9^{\mathrm{B}}$ & $131.0^{\mathrm{B}}$ & $203.2^{\mathrm{C}}$ & $343.9^{\mathrm{C}}$ & $\mathrm{DFB}=-182.661+7.499 * * *$ Age & 0.85 \\
\hline Mean & - & 2.1 & 10.9 & 158.5 & 344.5 & 697.3 & 1084.4 & & \\
\hline Rainy & $23.7^{\mathrm{A}}$ & $244.8^{\mathrm{A}}$ & $428.6^{\mathrm{A}}$ & $2312.2^{\mathrm{A}}$ & $2605.7^{\mathrm{A}}$ & $4837.0^{\mathrm{A}}$ & $4900.6^{\mathrm{A}}$ & GSB $=-1519.976+103.144 * * *$ Age & 0.90 \\
\hline Transition & $53.2^{\mathrm{A}}$ & $151.6^{\mathrm{A}}$ & $287.8^{\mathrm{A}}$ & $398.9^{\mathrm{B}}$ & $1055.5^{\mathrm{B}}$ & $1479.6^{\mathrm{B}}$ & $2307.1^{\mathrm{B}}$ & GSB $=-635.957+40.418 * * *$ Age & 0.86 \\
\hline Dry & $61.8^{\mathrm{A}}$ & $147.3^{\mathrm{A}}$ & $275.0^{\mathrm{A}}$ & $365.8^{\mathrm{B}}$ & $599.3^{\mathrm{B}}$ & $568.1^{\mathrm{C}}$ & $764.9^{\mathrm{C}}$ & GSB $=-70.443+12.996 * * *$ Age & 0.85 \\
\hline Mean & 46.2 & 181.2 & 330.5 & 1025.6 & 1420.1 & 2294.9 & 2657.5 & & \\
\hline Rainy & $65.6^{\mathrm{A}}$ & $631.4^{\mathrm{A}}$ & $1381.8^{\mathrm{A}}$ & $3879.8^{\mathrm{A}}$ & $3573.1^{\mathrm{A}}$ & $4841.8^{\mathrm{A}}$ & $4773.2^{\mathrm{A}}$ & GLB $=-798.319+98.154 * * *$ Age & 0.90 \\
\hline Transition & $94.9^{\mathrm{A}}$ & $362.8^{\mathrm{A}}$ & $606.0^{\mathrm{B}}$ & $802.3^{\mathrm{B}}$ & $2003.5^{\mathrm{B}}$ & $2586.5^{\mathrm{B}}$ & $3068.3^{\mathrm{B}}$ & GLB $=-748.657+58.590 * * *$ Age & 0.92 \\
\hline Dry & $109.1^{\mathrm{A}}$ & $344.4^{\mathrm{A}}$ & $677.8^{\mathrm{B}}$ & $873.4^{\mathrm{B}}$ & $1125.4^{\mathrm{C}}$ & $1222.6^{\mathrm{C}}$ & $2064.5^{\mathrm{C}}$ & GLB $=-236.095+32.023 * * *$ Age & 0.92 \\
\hline Mean & 89.9 & 446.2 & 888.5 & 1851.8 & 2233.9 & 2883.6 & 3302.0 & & \\
\hline
\end{tabular}

$\mathrm{GFB}=$ green forage biomass $\left(\mathrm{kg} \mathrm{ha}^{-1}\right), \mathrm{DFB}=$ dead forage biomass $\left(\mathrm{kg} \mathrm{ha}^{-1}\right), \mathrm{GSB}=$ green stem biomass $\left(\mathrm{kg} \mathrm{ha}^{-1}\right), \mathrm{GLB}=$ green leaf blade biomass $\left(\mathrm{kg}\right.$ ha $\left.^{-1}\right)$.

Means followed by the same letters in the same column did not differ ( $p>0.05)$ by Tukey's test.

Significant at the level of $0.1 \%(* * *), 1 \%(* *), 5 \%(*)$ of probability; R2 = coefficient of determination. 
Dead forage biomass (DFB) linearly increased with advancing age. Daily increases of 44.6, 20.8 and $7.5 \mathrm{~kg} \mathrm{ha}^{-1}$ day $^{-1}$ were observed for rainy, transition and dry seasons, respectively (Table 2 ). The highest daily increase in DFB in the rainy season was probably due to the rapid development of the leaf area index (LAI), which reached the critical level of interception of photosynthetically active radiation (PSAR) early, thereby accelerating the process of leaf senescence. Similar results were observed by Voltolini et al. (2010), who evaluated two graze intervals (95\% of PSAR and 26 fixed days) in an elephant grass canopy and verified a mean PSAR of $97.9 \%$ at 26 days, resulting in a higher amount of pregrazing DFB when compared to pastures managed with $95 \%$ of PSAR. Thus, optimal hasverting of the forage should occur between 36 and 45 days of age in the rainy season, as although that has not been evaluated in the present study, it possibly matches the moment when the canopy reaches the critical level of PSAR.

The reduction of soil matrix potential compromises translocation and absorption of nutrients by plants. Therefore, it is likely that the daily increase in DFB in the transition and dry seasons was more related to the mobilisation of nutrients from preexisting organs, to the cell expansion sites (TROUGHT \& DREW, 1980). The dry

season experienced the lowest water supply, justifying the higher participation of DFB in the total forage biomass (TFB; the sum of GFB and DFB), when compared to the previous seasons. This is because at 36 days of age, DFB represented $3.8 \%$ of TFB in the rainy and transition seasons, when at the same age in the dry season, DFB presented $5.0 \%$ of TFB. This indicates an intensification of quality loss of biomass compared to the other seasons, which does not justify prolongation of the cutting age of canopies under water restriction.

Green stem biomass (GSB) presented an increasing linear response as a function of age. Increases of 103.1, 40.4 and $12.3 \mathrm{~kg}$ $\mathrm{ha}^{-1}$ were estimated for each day of growth, in the rainy, transition and dry seasons, respectively (Table 2). The highest daily increases in GSB in the rainy season were possible due torainfall and the maintenance fertilisation carried out at the beginning of the experiment. Nitrogen fertilisation under satisfactory water conditions provides an increase in the stem elongation rate (COUTINHO et al., 2015) and larger stem diameters (TORRES et al., 2014). Although late cuttings provide a greater amount of harvestable biomass, the increase in rest period increased the participation of GSB in GFB. Daily increases of $103.14 \mathrm{~kg} \mathrm{ha}^{-}$ ${ }^{1}$ of GSB and only $98.15 \mathrm{~kg} \mathrm{ha}^{-1}$ of green leaf blade biomass (GLB) were estimated, indicating a progressive reduction in GFB quality, with the advancement of rest period in the rainy season. This is corroborated by the linear decrease of the leaf blade/stem ratio (Table 3). In the following seasons, the canopy presented lower GSB daily accumulation, investing more strongly in GLB with the increase of the plant'sage. The same behaviour was also demonstrated in the study of Kroth et al. (2015), who verified reduction of stem biomass as a response to the water deficit. The GLB responded increasingly with advancement of the plant's age (Table 2). The highest daily increase estimated as $98.15 \mathrm{~kg} \mathrm{ha}^{-1}$ in the rainy season compared to the other seasons, was due to the better rainfall distribution, along with the availability of nitrogen, which has great relevance to the morphogenic rates, as documented in the literature (LOPES et al., 2011; CANTO et al., 
2013). Araújo et al. (2010) observed a decline in the photosynthetic rate from the fifth day of water deficit in Pennisetum purpureum cv. Anão. Thus, the smallest daily GLB increases in the succeeding seasons $\left(58.6\right.$ and $32.0 \mathrm{~kg} \mathrm{ha}^{-}$

1 in the transition and dry seasons, respectively) can be attributed to the combined effect of water and nutritional restriction, which reduced the photosynthetic rates, reflecting lower leaf elongation rates. In this context, the combined effect of water availability (irrigation blades) and growth ages on the leaf photosynthesis rate (LOPES et al., 2013) are also added, as documented by previous authors who studied Brachiaria grass, where they found values of 37.7 $\mu \mathrm{mol} \mathrm{m} \mathrm{m}^{-2} \mathrm{~s}^{-1}$ with a daily irrigation blade of $3.84 \mathrm{~mm}$ at 10 days and $36.67 \mu \mathrm{mol} \mathrm{m}^{-}$ ${ }^{2} \mathrm{~s}^{-1}$ with an irrigation blade of $10.46 \mathrm{~mm}$ at 31 days, and minimum photosynthesis value $(34.84$

$\left.\mu \mathrm{mol} \mathrm{m} \mathrm{m}^{-2} \mathrm{~s}^{-1}\right)$ in the irrigation blade of $3.84 \mathrm{~mm}$ at 31 days, which was responsible for the lowest water supply for the maintenance of the plant's photosynthetic activity.

The live material/dead material ratio (LM/DM) presented a linear decreasing response with the advancement of age (Table 3). For each day of age, reductions of 12.0, 7.6 and 2.8 units of the LM/DM ratio were estimated for the rainy, transition and dry seasons, respectively. Despite the distinct daily reduction between seasons, no significant difference was observedafter

27 days of age. This shows that the different mechanisms that influenced senescence in the evaluated seasons impacted the response of this variable in a similar way.

The leaf blade/stem (LB/S) ratio linearly decreased in the rainy season, with reductions estimated as 0.041 units for each growing day. Thus, it is wise to manage the plant by aiming to harvest the forage at 59 days of age, when the $\mathrm{LB} / \mathrm{S}$ ratio reached the critical value of 1.0 (Table 3). In the transition season, a quadratic response was observed, with a maximum LB/S ratio of 2.6 at 27.53 days, indicating the harvest moment that would maximise the quality of the GFB produced in that period. In the dry season, the growth ages did not influence the $\mathrm{LB} / \mathrm{S}$ ratio, which presented a mean value of $2.22 \pm 0.27$. According to Pinto et al. (1994), the LB/S ratio is a qualitative indicator, assuming a critical value of 1.0, since lower values express a higher participation of stem in the GFB, which can compromise animal performance.

The lower increases in GSB in the transition and dry seasons contributed to the increase in the LB/S ratio, allowing the maintenance of values higher than

1.0. Although a higher $\mathrm{LB} / \mathrm{S}$ ratio suggests biomass of better qualitative value, it should be noted that the water restriction may reduce the quality of the leaf blades (SILVA et al., 2011). Forages that grow under water deficit in high temperature conditions present higher metabolic activity and lignification of the cell wall, causing the photoassimilates to be quickly converted into structural components (VAN SOEST, 1994). Despite the maintenance of values higher than 1.0, during transition and dry seasons, it is advisable to harvest the forage at earlier ages in order to avoid depletion of the biomass.

Height linearly increased with the advancement of plant age, in all seasons, with daily increases estimated as 3.13 , 1.49 and $0.76 \mathrm{~cm} \mathrm{day}^{-1}$ for the rainy, transition and dry seasons, respectively (Table 3). The tallest height estimated as $181.80 \mathrm{~cm}$ occurred at 63 days during the rainy season; however, based on the $\mathrm{LB} / \mathrm{S}$ ratio of 1.0 , obtained at 59.73 days, a height of $171.5 \mathrm{~cm}$ was estimated. 
Table 3. Structural characteristics of elephant grass cv. Roxo managed at different ages and seasons of growth

\begin{tabular}{|c|c|c|c|c|c|c|c|c|c|}
\hline \multirow{2}{*}{ Season } & \multicolumn{7}{|c|}{ Growth Age (days) } & \multirow{2}{*}{ Equation } & \multirow{2}{*}{$\mathrm{R}^{2}$} \\
\hline & 9 & 18 & 27 & 36 & 45 & 54 & 63 & & \\
\hline Rainy & - & $658.5^{\mathrm{A}}$ & $176.1^{\mathrm{A}}$ & $15.0^{\mathrm{A}}$ & $9.2^{\mathrm{A}}$ & $7.4^{\mathrm{A}}$ & $4.9^{\mathrm{A}}$ & $\mathrm{LM} / \mathrm{DM}=631.140-11.998 * * *$ Age & 0.60 \\
\hline Transition & - & $315.8^{\mathrm{B}}$ & $279.6^{\mathrm{A}}$ & $38.4^{\mathrm{A}}$ & $14.8^{\mathrm{A}}$ & $7.1^{\mathrm{A}}$ & $5.8^{\mathrm{A}}$ & $\mathrm{LM} / \mathrm{DM}=417.675-7.590 * * *$ Age & 0.60 \\
\hline Dry & - & $147.7^{\mathrm{B}}$ & $55.1^{\mathrm{A}}$ & $46.6^{\mathrm{A}}$ & $13.5^{\mathrm{A}}$ & $9.8^{\mathrm{A}}$ & $7.4^{\mathrm{A}}$ & $\mathrm{LM} / \mathrm{DM}=158.64-2.760 * * *$ Age & 0.66 \\
\hline Mean & - & 374.0 & 170.3 & 33.7 & 12.5 & 8.1 & 6.0 & & \\
\hline Rainy & $2.8^{\mathrm{A}}$ & $2.6^{\mathrm{A}}$ & $3.3^{\mathrm{A}}$ & $1.7^{\mathrm{A}}$ & $1.4^{\mathrm{A}}$ & $1.0^{\mathrm{B}}$ & $0.9^{\mathrm{B}}$ & $\mathrm{LB} / \mathrm{S}=3.449-0.041 * * *$ Age & 0.76 \\
\hline Transition & $1.8^{\mathrm{B}}$ & $2.4^{\mathrm{A}}$ & $2.1^{\mathrm{AB}}$ & $2.0^{\mathrm{A}}$ & $1.9^{\mathrm{A}}$ & $1.8^{\mathrm{AB}}$ & $1.3^{\mathrm{AB}}$ & $\begin{array}{l}\mathrm{LB} / \mathrm{S}=1.658+0.036^{* *} \text { Age }-0.0006^{* * *} \\
\mathrm{Age}^{2}\end{array}$ & 0.75 \\
\hline Dry & $1.8^{\mathrm{B}}$ & $2.4^{\mathrm{A}}$ & $2.4^{\mathrm{B}}$ & $2.5^{\mathrm{A}}$ & $1.9^{\mathrm{A}}$ & $2.2^{\mathrm{A}}$ & $2.4^{\mathrm{A}}$ & $\mathrm{LB} / \mathrm{S}=2.22 \pm 0.27$ & - \\
\hline Mean & 2.1 & 2.4 & 2.6 & 2.2 & 1.7 & 1.7 & 1.6 & & \\
\hline Rainy & $18.8^{\mathrm{A}}$ & $33.2^{\mathrm{A}}$ & $67.5^{\mathrm{A}}$ & $96.4^{\mathrm{A}}$ & $127.0^{\mathrm{A}}$ & $160.2^{\mathrm{A}}$ & $177.5^{\mathrm{A}}$ & $\mathrm{H}=-15.595+3.133^{* * *}$ Age & 0.99 \\
\hline Transition & $16.0^{\mathrm{A}}$ & $22.7^{\mathrm{B}}$ & $36.0^{\mathrm{B}}$ & $51.6^{\mathrm{B}}$ & $71.1^{\mathrm{B}}$ & $81.6^{\mathrm{B}}$ & $90.3^{\mathrm{B}}$ & $\mathrm{H}=-0.912+1.490^{* * *}$ Age & 0.97 \\
\hline Dry & $13.6^{\mathrm{A}}$ & $22.6^{\mathrm{B}}$ & $29.8^{\mathrm{B}}$ & $41.2^{\mathrm{C}}$ & $53.3^{\mathrm{C}}$ & $47.5^{\mathrm{C}}$ & $53.0^{\mathrm{C}}$ & $\mathrm{H}=9.914+0.760 * * *$ Age & 0.89 \\
\hline Mean & 16.1 & 26.1 & 44.4 & 63.0 & 83.8 & 96.4 & 106.9 & & \\
\hline Rainy & $0.2^{\mathrm{A}}$ & $2.2^{\mathrm{A}}$ & $4.2^{\mathrm{A}}$ & $10.8^{\mathrm{A}}$ & $9.7^{\mathrm{A}}$ & $12.4^{\mathrm{A}}$ & $11.5^{\mathrm{A}}$ & $\mathrm{LAI}=-1.394+0.234 * * *$ Age & 0.92 \\
\hline Transition & $0.4^{\mathrm{A}}$ & $1.3^{\mathrm{AB}}$ & $1.5^{\mathrm{B}}$ & $1.8^{\mathrm{B}}$ & $5.6^{\mathrm{B}}$ & $5.9^{\mathrm{B}}$ & $6.76^{\mathrm{B}}$ & $\mathrm{LAI}=-1.269+0.128 * * * \mathrm{Age}$ & 0.88 \\
\hline Dry & $0.4^{\mathrm{A}}$ & $0.9^{\mathrm{B}}$ & $1.5^{\mathrm{B}}$ & $1.8^{\mathrm{B}}$ & $2.1^{\mathrm{C}}$ & $1.9^{\mathrm{C}}$ & $2.70^{\mathrm{C}}$ & $\mathrm{LAI}=0.227+0.039 * * * \mathrm{Age}$ & 0.78 \\
\hline Mean & 0.3 & 1.5 & 2.4 & 4.8 & 5.8 & 6.7 & 6.9 & & \\
\hline Rainy & $75.0^{\mathrm{B}}$ & $113.0^{\mathrm{A}}$ & $153.0^{\mathrm{A}}$ & $148.0^{\mathrm{A}}$ & $91.0^{\mathrm{A}}$ & $61.0^{\mathrm{B}}$ & $50.0^{\mathrm{A}}$ & $\begin{array}{l}\text { TPD }=33.667+6.435 * * * \text { Age }-0.103 * * * \\
\text { Age }^{2}\end{array}$ & 0.77 \\
\hline Transition & $115.0^{\mathrm{A}}$ & $89.0^{\mathrm{A}}$ & $71.0^{\mathrm{B}}$ & $63.0^{\mathrm{C}}$ & $98.0^{\mathrm{A}}$ & $112.0^{\mathrm{A}}$ & $77.0^{\mathrm{A}}$ & $\mathrm{TPD}=123.619-2.254^{\wedge} \mathrm{Age}+0.029^{\boldsymbol{\Lambda}} \mathrm{Age}^{2}$ & 0.20 \\
\hline Dry & $93.0^{\mathrm{AB}}$ & $101.0^{\mathrm{A}}$ & $102.0^{\mathrm{B}}$ & $111.0^{\mathrm{B}}$ & $99.0^{\mathrm{A}}$ & $121.0^{\mathrm{A}}$ & $83.0^{\mathrm{A}}$ & $\mathrm{TPD}=76.904+1.795 *$ Age $-0.024 *$ Age $^{2}$ & 0.20 \\
\hline Mean & 94.4 & 101.4 & 109.1 & 107.7 & 96.3 & 98.1 & 70.4 & & \\
\hline
\end{tabular}

$\mathrm{LM} / \mathrm{DM}=$ live material/dead material ratio, $\mathrm{LB} / \mathrm{S}=$ leaf blade/stem ratio, $\mathrm{H}=$ height $(\mathrm{cm}), \mathrm{LAI}=$ leaf area index, $\mathrm{TPD}=$ tiller population density.

Means followed by the same letters in the same column did not differ $(p>0.05)$ using Tukey's test.

Significant at the levels of $0.1 \%(* * *), 1 \%(* *), 5 \%(*)$ and $10 \%(\boldsymbol{\Delta})$ of probability; $\mathrm{R}^{2}=$ coefficient of determination 
Perazzo et al. (2013) observed higher biomass production in Sorghum genotypes of larger size. In the present study, there was a good positive correlation between height and GFB ( $\mathrm{r}$ $=0.98, \mathrm{p}<0.0001)$ and height and GSB $(\mathrm{r}$ $=0.96, \mathrm{p}<0.0001)$, indicating a relevant contribution of the increase in stem with the increase in height of the plant, reaffirming the positive correlation between pseudo stem height and canopy height (CASTAGNARA et al., 2011)

Possibly the highest LAI values in the rainy season intensified mutual shading, which triggered the stem elongation process (DAVIS \& SIMMONS, 1994).

This was confirmed by a negative correlation $(\mathrm{r}=-0.75, \quad \mathrm{p}<0.0001)$ between the LB/S ratio and GSB. Stem elongation allowed spacing of the insertion point of the leaf blades, making an architectural rearrangement in order to better allow distribution of the solar radiation along the canopy profile (ALEXANDRINO et al., 2011). This was not observed in the succeeding seasons, possibly because the negative water balance prevented the LAI from reaching critical levels (PEREIRA et al., 2014). The water restriction compromises cell turgescence pressure, a mechanism that is part of the cellular expansion process; this contributed to the smallest daily increases in height in those seasons.

The LAI presented a linear positive response with the increase in growth age in the three evaluated seasons (Table 3). The rest period fixed at 63 days allowed a continuous increase in leaf area, which probably led to an increase in the coefficient of light extinction and mutual shading; this may have compromised the distribution of active photosynthetic radiation (APR) and photosynthesis of the lower leaves (BRAGA et al., 2009), up to a climax moment. From this point, there was a significant increase in the senescence of shaded stems and leaf blades, which was demonstrated by a significant correlation between LAI and DFB $(r=0.85$, $\mathrm{p}<0.0001$ ), revealing the negative effects of postponing the harvest. Possibly, the reduction in LAI between the transition and dry seasons consisted of an adaptive response of the grass, allowing less water loss via leaf area with the same number of structural units, since the number of tillers in the later evaluated ages did not differ.

Tiller population density (TPD) showed a quadratic response to advancement in growth age, with maximum values estimated as 134.0 , and 110.0 til. $\mathrm{m}^{-2}$ at 31.24 and 37.40 days for the rainy and dry seasons, respectively (Table 3 ). After those ages, there was a continuous reduction in TPD and investment of photoassimilates in individual tillers, consequently potentialising an increase in GSB and a decrease in GFB. Possibly after 31.24 days, in the rainy season, there was an intensification in the reduction of the red:far red ratio at the base of the canopy, preventing the development of basilar buds (FIALHO et al., 2012). In the transition season, the minimum TPD of 79 til. $\mathrm{m}^{-2}$ was estimated at 38.7 days. The number of tillers is a characteristic of strong genetic character, which may explain the fact that there was no significant difference for some ages between transition and dry seasons (SILVA et al., 2010). In the last two seasons, there was variation in the magnitude of TPD, probably due to the dispersed precipitation that occurred during those seasons.

In conclusion, the seasonality of rainfall influenced the magnitude of the daily increase in the different components of the biomass in Pennisetum purpureum cv. Roxo. 
The harvest frequency of elephant grass cv. Roxo conditions should not be based on chronological age without considering the environmental variables extrinsic to the canopy.

The harvesting frequency of Pennisetum purpureum cv. Roxo managed under the water deficit adopted, should enable the highest number of cycles in the season of greatest water availability, leading to a greater biomass daily accumulation.

\section{REFERENCES}

ALENCAR, C.A.B.; CÓSER, A.C.; OLIVEIRA, R.A.; MARTINS, C.E.; CUNHA, F.F.; FIGUEIREIDO, J.L.A. Produção de seis gramíneas manejadas por corte sob efeito de diferentes lâminas de irrigação e estações anuais. Revista Ciência e Agrotecnologia [online] v.33, n.5, p.1307-1313, 2009.

\section{ALEXANDRINO, E; CANDIDO,} M.J.D.; GOMIDE, J.A. Fluxo de biomassa e taxa de acúmulo de forragem em capim Mombaça mantido sob diferentes alturas. Revista Brasileira de Saúde e Produção Animal [online], v.12, n.1, p.59-71, 2011.

ANDRADE, I.F., GOMIDE, J.A. Curva de crescimento e valor nitritivo do capimelefante (Pennisetum purpureum Schum) Taiwan A-146. Revista Ceres [online], v.18, n.100, p.431-437, 1971.

ARAÚJO, S.A.C.; VASQUEZ, H.M.; CAMPOSTRINI, E.; NETTO, A.T.; DEMINICIS, B.B.; LIMA, E.S.

Características fotossintéticas de genótipos de capim-elefante anão (Pennisetum purpureum Schum.), em estresse hídrico. Acta Scientiarum. Animal Sciences [online], v.32, n.1, p.17, 2010.
BENINCASA, M.M.P. Análise de crescimento de plantas: noções básicas. Jaboticabal: FUNEP, 2003. $42 \mathrm{p}$.

BRAGA, G.J.; MELLO, A.C.L.; PEDREIRA, C.G.S.; MEDEIROS, H.R. Fotossíntese e taxa diária de produção de forragem em pastagens de capimtanzânia sob lotação intermitente. Pesquisa Agropecuária Brasileira [online], v.44, n.1, p.84-91, 2009.

CANTO, M.W.; HOESCHL, A.R.; FILHO, A.B; MORAES, A.

Características do pasto e eficiência agronômica de nitrogênio em capimtanzânia sob pastejo contínuo, adubado com doses de nitrogênio. Ciência Rural [online], v.43, n.4, p.682-688, 2013.

CASTAGNARA, D.D.; MESQUITA, E.E.; NERES, M.A.; OLIVEIRA, P.S.R.; DEMINICIS, B.B.;

BAMBERG, R. Valor nutricional e características estruturais de gramíneas tropicais sob adubação nitrogenada. Archivos de Zootecnia [online], v.60 n.232, p. 931-942. 2011.

CHAPMAN, D.F.; LEMAIRE, G. Morphogenetic and structural determinants of plant regrowth after defoliation. In: BAKER, M.J (Ed.) Grasslands for our world. Wellington: SIR Publishing, 1993. p.55-64.

COMISSÃO DE FERTILIDADE DO SOLO DO ESTADO DE MINAS GERAIS - CFSEMG. Recomendações para uso de corretivos e fertilizantes em Minas Gerais - $5^{\mathrm{a}}$ Aproximação. 5. ed. Viçosa: Universidade Federal de Viçosa, 1999. 359p. 
COUTINHO, M.J.F.; CARNEIRO, M.S.S.; EDVAN, R.L.; SANTIAGO, F.E.M.; ALBUQUERQUE, D.R. Características morfogênicas, estruturais e produtivas de capim-buffel sob diferentes turnos de rega. Pesquisa Agropecuária Tropical [online], v.45, n.2, p.216-224, 2015.

DAVIDSON, L.; MILTHORPE, F. L. The Effect of Defoliation on the Carbon Balance in Dactylis glomerata. Annals of Botany [online], v.30, n.118, p.185198, 1966.

DAVIS, M.N.; SIMMONS, S.R. Far-red light reflected from neighbouring vegetation prometes shoot elongation and accelerates flowering in spring barley plants. Plant Cell and Environment [online], v.17, p.829-836, 1994.

DONG, X.; PATTON, J.; WANG, G.; NYREN, P.; PETERSON, P. Effect of drought on biomass allocation in two invasive and two native grass species dominating the mixed-grass Prairie. Grass and Forage Science [online], v.69, p.160-166, 2012.

FIALHO, C.A.; SILVA, S.C.; GIMENES, F.M.A.; GOMES, M.B.; BERNDT, A.; GERDES, L. Tiller population density and tillering dynamics in marandu palisade grass subjected to strategies of rotational stocking management and nitrogen fertilization. Acta Scientiarum. Animal Sciences [online], v.34, p.137-139, 2012.

KROTH, B.E.; BONFM-SILVA, E.M.; SILVA T.J.A.; MARCIO KOETZ \& ALESSANA F. Cultivares de Brachiaria brizantha sob diferentes disponibilidades hídricas em Neossolo Flúvico. Revista Brasileira de Engenharia Agrícola e Meio Ambiente [online], v.19, n.5, p.464-469, 2015.

SHARP, R.E. Interaction with ethylene:
LOPES, M.N.; CÂNDIDO, M.J.D.; POMPEU, R.C.F.F.; SILVA, R.G.; BEZERRA, F.M.L. Componentes estruturais do resíduo pós-corte em capim-massai adubado com cinco doses de nitrogênio. Revista Ciência Agronômica [online], v.42, n.2, p.518$525,2011$.

LOPES, M. N.; POMPEU, R.C.F.F.; SILVA, R.G.; FILHO, J.G.L.R.; BESERRA, L.T.; LACERDA, C.F. Trocas gasosas e índices de crescimento em capim-braquiária manejado sob lâminas de irrigação e idades de crescimento. Revista Agro@mbiente [online], v.7, n.1, p.10-17, 2013.

PERAZZO, A.F.; SANTOS. E.M.; PINHO, R.M.A.; CAMPOS, F.S.; RAMOS, J.F.; AQUINO, M. M.; SILVA, T.C.; BEZERRA, H.F.C. Características agronômicas e eficiência do uso da chuva em cultivares de sorgo no semiárido. Revista Ciência Rural [online], v.43, n.10, p.1771-1776, 2013.

PEREIRA, T.P.; MODESTO, E.C.; CAMPANA, L.L.; GOMIDE, C.A.M.; PACIULLO, D.S.C.; NEPOMUCENO, D.D.; CARVALHO, C.A.B.; MORENZ, M.J.F.; ALMEIDA, J.C.C. Caracterização da forragem e da extrusa de clones de capim elefante anão sob lotação intermitente. Semina: Ciências Agrárias [online], v.35, n.5, p.26352648, 2014.

PINTO, J.C.; GOMIDE, J.A.; MAESTRI, M. Produção de matéria seca e relação folha/caule de gramíneas forrageiras tropicais, cultivadas em vasos, com duas doses de nitrogênio. Revista Brasileira de Zootecnia [online], v.23, n.3, p.313-326, 1994.

SAS Institute. SAS System for Windows. Version 9.0. Cary, 2002.

changing views on the role of abscisic acid in root and shoot growth responses 
to water stress. Plant Cell and Environment [online], v.25, n.2, p.211$222,2002$.

SILVA, A.L.C.; SANTOS, M.V.F.; FERREIRA, R.L.C.; JÚNIOR, J.C.B.D.; LIRA, M.A.; CUNHA, M.V.; PEREIRA, A.V.; ARAÚJO, G.G.L. Variabilidade e herdabilidade de caracteres qualitativos relacionados à qualidade de forragem de clones de capim-elefante na Zona da Mata de Pernambuco. Revista Brasileira de Zootecnia [online], v.40, n.1, p.39-46, 2011.

SILVA, A.L.C.; SANTOS, M.V.F.; JÚNIOR, J.C.B.D.; LIRA, M.A.; FERREIRA, R.L.C.; FREITAS, E.V.; CUNHA, M.V.; SILVA, M.C. Variabilidade e herdabilidade de caracteres morfológicos em clones de capim-elefante na Zona da Mata de Pernambuco. Revista Brasileira de Zootecnia [online], v.39, n.10, p.21322140, 2010.

TORRES, F.E.; SOUZA, L.C.F.; ANDRADE L.H.L.; PEDROSO, F.F.; MATOSO, A.O.; TORRES, L.D.; BENETT, C.G.S.; BENETT, K.S.S. Influência da cobertura do solo e doses de nitrogênio na cultura do milho safrinha. Revista Brasileira de Ciências Agrárias [online], v.9, n.1, p.36-41, 2014.

TROUGHT, M.C.T.; DREW, M.C. The development of waterlogging damage in wheat seedlings (Triticum aestivum L.): II - Accumulation and redistribuition of nutrients by the shoot. Plant and Soil, v.56, n.2, p.187-199, 1980.
VAN SOEST, P.J. Nutritional Ecology of the Ruminant. 2.ed.Ithaca: Cornell University, p.476, 1994.

VOLTOLINI, T.V.; SANTOS, F.A.P.; MARTINEZ, J.C.; CLARINDO, R.L.; PENATI, M.A.; IMAIZUMI, H. Características produtivas e qualitativas do capim-elefante pastejado em intervalo fixo ou variável de acordo com a interceptação da radiação fotossinteticamente ativa. Revista Brasileira de Zootecnia [online], v.39, n.5, p.1002-1010, 2010.

Receipt date: 14/09/2017 Approval date: 04/01/2018 
Errata

No artigo "Biomass components of Pennisetum purpureum cv. Roxo managed at different growth ages and seasons"; DOI: 10.1590/S1519-99402018000100002; v.19, n.1, p.11-22 jan./mar., 2018, na página 11:

Onde se lia:

"POMPEU, Roberto Claudio Fernandes Franco"

Leia-se:

"POMPEU, Roberto Cláudio Fernandes Franco"

Onde se lia:

"SILVEIRA, Francisco Gleyson Alves da"

Leia-se:

"ALVES, Francisco Gleyson da Silveira"

Onde se lia:

"Pennisetum purpureum"

Leia-se:

"Capim-elefante" 